\title{
nature
}

\section{The unacceptable face of nationalism}

\section{Unless the fiercer manifestations of nationalism are subdued, European cooperation, in both politics and science, has no future.}

THE proud image of France has taken a fearful battering in recent weeks, culminating in the public admission on Sunday by Prime Minister Laurent Fabius of the "bitter truth" that the French secret service, the DGSE, had sunk the Rainbow Warrior, flagship of the environmental organization Greenpeace, and moreover that the DGSE had acted "under orders". Whose orders, it is not yet clear, and it must be uncertain in such tangled affairs whether even the parliamentary inquiry requested by $M$. Fabius will arrive at the final, unvarnished truth of the matter. As M. Fabius well knows, socialist members will wish to protect their government; and the right wing will protect the DGSE and the extreme nationalistic sentiments it represents, along with the nuclear deterrant and the glory of France. In the secret service of any government, be it French, British, American or Soviet, truth and fiction are interchangeable at many levels.

But above this noise, there is one clear signal: rampant nationalism has gone too far. Sentiments have been voiced and acted upon in France that raise "the nation" into the same kind of radiant divinity, bearing no relation to reality, that has motivated far worse crimes in human history than France's single, unintended murder in Auckland - however abhorrent that crime might be.

France, of course has long had a reputation for being strongly nationalistic - and not just among the British who seem to find the French strangely attached to their own language. Let us be clear.immediately, post-war history shows that France is not alone in its excessive pride - surely Britain and France together are the nationalists of Europe, both resting culturally on the laurels of empire - but it is France, for the moment, that has brought itself into the public eye. And France has been nationalistic not only to its nuclear weapons testing in the South Pacific, and its consequent attack on the Rainbow Warrior, but also in another area of its policy, that of European cooperation in research and technology.

\section{Eureka}

Thus Eureka, the French initiative in European cooperation in the development of new high technology products, while avowedly European, has been compromised by French attempts to dominate the programme. France, it seems, wishes to see a new Europe, provided it is led by France. How else is it possible to interpret the strong French effort at the first ministerial meeting on Eureka this spring to set up a Eureka secretariat in Paris, despite an avowed French intention that Eureka projects should have ad hoc management structures? Britain rejected the proposal. How else can one interpret the French attitude to the European advanced fighter concept (the EFA), of which again France wished to have the lion's share, and which France finally left to the rest of Europe to develop while its own manufacturers went their own way?

How else, furthermore, can one interpret the mysterious French insistance that the European Commission shall not be involved in Eureka? Here the arguments are many, but it was clear from the beginning that Eureka had hijacked the whole spirit of the commission's Esprit programme in information technology, which had been brilliantly set up by the Belgian ex-commissioner Etienne Davignon. Yet it seemed many months before French research minister Hubert Curien reluctantly admitted his debt. The European Commission feels "by-passed" by Eureka. The argument for this position is that the Commission is too slow and bureaucratic. But if this is so it is often because the Council of Ministers - the representatives of the nation-states of Europe - tamper with Commission initiatives until they become too watered down, too late or too little (thus it was with biotechnology). What, then, will be different about Eureka? Will not the nationalistic sentiments that the European Community was precisely founded to calm. and which are so evident in the Greenpeace affair, get greater rein?

Eureka proponents talk of "flexibility" and "variable geometry" - which means different nations can participate in different projects, and that nations outside the EEC can join in. But the former was already the case under Esprit, and the latter under many long-standing Commission programmes in the COST (cooperation in science and technology) umbrella. Why, then, is Eureka by-passing the European Commission? Is it realism? Or is it really a nationalism which will threaten to fragment true cooperation?

\section{Remedies}

We shall see how things turn out at the next ministerial meeting on Eureka in Hannover in November. And may they turn out well, for finally there is only one cure for excessive attention to the national interest, and that is the creation of an international interest. Thus only when more and more jobs, and with them political power and influence, begin to depend on true European collaboration, will a real Europe emerge and the old jingoisms subside. It is a thought that applies just as well to the North-South divide - and in particular to France and the South Pacific. There, President Mitterrand has warned that he will defend the French national interest in the weapons tests on Muroroa atoll "by force", against a new Greenpeace flotilla now converging on the area. It might be better for French interests in the rapidly growing economy of the Pacific, and for world harmony, if he took a more pacific, and economic, line.

But glory is France's, and perhaps even America's, constitutional dilemma. As George Orwell, the British socialist writer, once pointed out, the advantage of a constitutional monarchy is that it succeeds in separating the glory of kingship from the power of government. In France, de Gaulle's presidential constitution combines both. It was once said --by a Frenchman - that France is a kingdom, but Britain a republic. And now that the survival of President Mitterrand's presidency into its final two years is surely threatened by the Greenpeace affair, perhaps there is a chance for some constitutional amendment - not, of course, to restore a monarchy, but at least to reduce the glory of the presidency by reducing the term of office from seven years to the present five years the government enjoys.

In the United States, it was the impeachment of President Nixon over the Watergate affair that moderated the glory of the presidency, and marked out the limits of its power; in France it may not be any Greenpeace investigation per se but a little constitutional amendment down the line that is what the doctor ordered. 